\title{
Theologians and Their Bellies
}

\section{The Erasmian Epithet Theologaster during the Reformation}

\author{
Maciej Ptaszyński | oRCID: 0000-0003-2508-061X \\ University of Warsaw, Warsaw, Poland \\ m.ptaszynski@uw.edu.pl
}

\begin{abstract}
An analysis of the role and meaning of the epithet "theologaster," coined by Erasmus of Rotterdam in his letter from Paris in 1497, can reward us with insights into the interplay of Reformation, scholastic, and humanist forces in the sixteenth century. Although Erasmus rarely used the term in his later correspondence or in his works, the epithet gained some popularity among the humanists and the reformers. During the confessional debates, both sides, the Catholics and the Protestants in the Holy Roman Empire and in France, reached for this same epithet as an argument and a weapon with which to demonstrate the incompetence of their opponents. The term, however, can rarely be found in the confessional polemics in Poland, despite the enormous popularity of Erasmus in the region. The history of the epithet sheds light on the importance of the humanist legacy for the confessional era.
\end{abstract}

\section{Keywords}

Reformation - humanism - confessionalization - Melanchthon - confessional polemics

\section{Introduction}

In August 1497, Erasmus of Rotterdam, who was thirty at the time, sent a very bitter letter from Paris. ${ }^{1}$ Writing to his younger colleague and former pupil, Thomas Grey, the humanist painted a somber picture of the Parisian univer-

1 Ep. 64. 
sity, where he was obliged to remain in order to obtain his degree of Doctor of Theology. As a former theologian turned Scotist (ego, ille vetus theologus, nuper Scotista), he had forgotten the art of writing. Erasmus expressed his complaints against scholasticism in an anecdote that was as purposefully intricate as scholastic thought itself. In a highly ironic style, Erasmus related his "theological sleep," in which the Cretan philosopher Epimenides-known for describing all Cretans as liars (Tit. 1:12) —was also the greatest scholastic the-

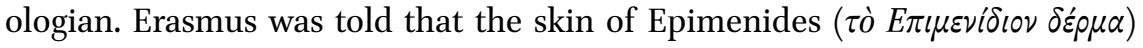
was worshipped at the Sorbonne almost as a relic. The Cretan published a book containing syllogisms so complex that even he would have been unable to understand his own productions - had he not been a prophet. In the tale recounted by Erasmus, Epimenides went for a walk and, finding himself tired, dozed off and fell into a theological sleep (imo somnus ille theologicus) that lasted forty-seven years. After he awoke, he returned to the city, where-with no one recognizing him-he became the object of mockery. What had he been dreaming about all those years? The most subtle subtleties (subtilissimas subtilitates) were currently taught by Scotists, Erasmus averred, since the 'Subtle Doctor' himself, the Scottish philosopher-theologian Duns Scotus (d. 1308), was in fact Epimenides reborn.

The elaborate story of a dream within a dream (Erasmus dreaming about Epimenides, who is dreaming about subtleties) was, of course, an erudite joke about the Academy that found its place in the Adagia published by the humanist a decade later. ${ }^{2}$ In his letter, Erasmus added that he would merely frown and raise his eyebrows during lectures, not understanding a thing and trying not to speak a word of proper Latin, which is why Grey should not expect any of his former style or wit in the present letter. The humanist concluded his deliberations with an explanation that the joke was not aimed against theology, but the style-over-substance theologasters: "I would not have you mistakenly infer that what I have just written was directed against theology itself, to which, as you are aware, I have always been deeply devoted. I merely wished to make a joke at the expense of a few quasi-theologians [theologastros] of our own day, whose brains are the most addled, tongues the most uncultured, wits the dullest, teaching the thorniest, characters the least attractive, lives the most hypocritical, talk the most slanderous, and hearts the blackest on earth." ${ }^{3}$

2 Adage 864 Ultra Epimenidem dormis.

3 Ep. 64 CWE lines 94-101, Allen lines 86-92: "nolim haec interpreteris in ipsam dicta theologiam, quam, ut scis, unice semper colui; sed in nostrae tempestatis theologastros quosdam iocari libuit, quorum cerebellis nihil putidius, lingua nihil barbarius, ingenio nihil stupidius, 
The letter is well-known and cited in many classical biographies of Erasmus as being the only testimony of his studies and the flourishing of his historical awareness, as well as evidence of the close relationship between the humanist and the young Grey. ${ }^{4}$ The content and character of the epistle should come as no surprise: Erasmus, in his typical style, condemned scholasticism and scholastics, yet did so while holding the shield of a story within a story and a slightly convoluted metaphor. The humanist believed that scholastic theologians treated their abstract deliberations as an objective in itself, since they contributed neither to a broadening of knowledge about God nor to an amelioration of the quality of human life. Consequently, schoolmen were the new barbarians, being both mentally and morally deficient. These criticism-found in the works of Francesco Petrarca, Giovanni Pico della Mirandola, and other early humanists - were already present in Antibarbari, most likely written by Erasmus in 1489 or 1493 , revised in 1517 , and published in $1520,{ }^{5}$ and in the famous Praise of Folly, first published in 1511, and continually sparking controversy after the outbreak of the Reformation. ${ }^{6}$ However, in his letter to Grey Erasmus used a new word to describe scholastics: theologastri.

In the discussion that follows, the meaning and history of this term are outlined. The argument aims to trace the complex paths of reception and usage of the insult in European religious disputations of the sixteenth century. The deliberations below set out to prove that the changing meaning of theologaster reflects the development of the Reformation in Europe, shedding new light on the cultures of conflict, which were not just petty squabbles between the-

doctrina nihil spinosius, moribus nihil asperius, vita nihil fucatius, oratione nihil virulentius, pectore nihil nigrius."

4 Paul Mestwerdt, Die Anfänge des Erasmus. Humanismus und Devotio moderna. Studien zur Kultur und Geschichte der Reformation (Leipzig: R. Haupt, 1917) 316-317; Johan Huizinga, Erasmus and the Age of Reformation, tr. F. Hopman, B. Flower (Princeton, NJ: Princeton University Press, 1984) 23f.; James D. Tracy, Erasmus. The Growth of a Mind (Genève: Droz, 1972) 66-68; Robert Stupperich, Erasmus von Rotterdam und seine Welt (Berlin: De Gruyter, 1977) 46-47; Erica Rummel, Erasmus as a Translator of the Classics (Toronto: University of Toronto Press, 1985) 9; Richard J. Schoeck, Erasmus of Europe. The Making of a Humanist 1567-1500 (Edinburgh: University Press, 199o) 66-67; Peter Fabisch, Iulius exclusus e coelis: Motive und Tendenzen gallikanischer und bibelhumanistischer Papstkritik im Umfeld des Erasmus (Münster: Aschendorff, 2008) 235-240; Christine Christ-von Wedel, Erasmus of Rotterdam: Advocate of a New Christianity (Toronto: University of Toronto Press, 2013) 27-31.

5 K. Kumaniecki, Introduction in ASD I-1: 7-32; István Bejczy, Erasmus and the Middle Ages: the historical consciousness of a Christian humanist (Leiden: Brill, 2001) 8-32; J. Ledo, "From Wit to Shit: Notes for an 'Emotional' Lexicon of Sophistry during the Renaissance," Philosophical Readings 11 (2019) 103-119. http://doi.org/10.5281/zenodo.2555148.

6 C.H. Miller, Introduction in ASD IV-3: 13-64; see more generally, Erika Rummel, Erasmus and his Catholic Critics (Nieuwkoop: de Graaf, 1989). 
ologians (rabies theologorum); but instead made a significant contribution to shaping confessional identities in the modern era. ${ }^{7}$

\section{$2 \quad$ Word by Word}

As claimed in modern dictionaries, the term used by Erasmus in his letter to Grey was a neo-Latin neologism most likely invented by Erasmus himself. ${ }^{8}$ The humanist coined it in imitation of pejorative expressions known from classical Latin, formulated using the suffix -aster and denoting incompetence. The most popular terms created based on this model and used both in classical and Renaissance Latin were poetaster (pseudo-poet) and philosophaster (pseudophilosopher), with patraster (father-in-law, stepfather) sharing the same form, though evoking slightly different connotations, also expressing scorn. ${ }^{9}$

Although the structure and meaning of the term should be straightforward, laymen could and still can find it misleading, since it suggests a compound of "theology" and -gaster or -gastrum, a Latin word of Greek origin ( $\gamma \alpha \sigma \tau \dot{p} \rho)$ that meant "stomach" or "belly." While this could serve as a classic case of false etymology, which is a rather frequent phenomenon, it cannot be ruled out that the readers and author alike were also aware of this ambiguity. The notion would be in line with allegations often cast at sixteenth-century clergymen, namely that their lifestyle had begun to dangerously resemble that of laypersons. Throughout Europe, churchmen were often accused of abusing the pleasures of the table and the bedroom, and in these anticlerical discourses the biblical figure of the belly (Phil. 3:19) became a symbol of broadly understood sensuality and sin, exemplifying the ever stronger aversion to obesity. ${ }^{10}$ Sixteenth-century French

See I. Dingel, "The Culture of Conflict in the Controversies Leading to the Formula of Concord (1548-1580)" in Lutheran Ecclesiastical Culture, 1550-1675, ed. R. Kolb (Leiden: Brill, 2008) 15-64; compare also M. Pohlig, "Harter Kern und longue durée. Überlegungen zum Begriff der (lutherischen) Konfessionskultur," Archiv für Reformationsgeschichte 109 (2018) 389-401 (391).

8 See entries in René Hoven, Lexique de la prose latine de la Renaissance (Leiden: Brill, 2006) 564; The Oxford English Dictionary, ed. J.A. Simpson, E.S.C. Weiner, vol. 17 (Oxford: Oxford University Press, 1989) 896; Französisches Etymologisches Wörterbuch, hrsg von. W. von Wartburg, vol. 13, 1 (Basel: Zbinden, 1966) 304; Grande Dizionario della lingua italiana, ed. S. Battaglia, vol. 20 (Torino: Unione Tip.-Ed 200o) 911. There is no entry in the Grimms' Dictionary, see http://dwb.uni-trier.de/de/.

9 See Thesaurus Linguae Latinae, vol. 10, 1: 2024 ("philosophaster"); online: www.thesaurus .badw-muenchen.de.

10 Georges Vigarello, Les métamorphoses du gras: histoire de l'obésité du Moyen âge au XXe siècle (Paris: Éd. Points, 2013) 66-154. 
expressions les théologiens du ventre, les ventres théologiques, or les penseurs de la panse were formulated in the same vein." The greatest examples of these accusations may be found in François Rabelais' monumental work Gargantua and Pantagruel, which, admittedly, did not feature the word theologastri, but theologians were repeatedly insulted therein using terms such as "Sorbillans, Sorbonigènes, Sorbonicoles, Xorboniformes, Sorbonisecques, Niborcisans, Saniborsans."12 As controversially argued by Mikhail Bakhtin, the "lower stratum," which also included the belly and the sphere of sensuality, was one of the fundamental axes of Rabelais' narrative and a reflection of the popular culture. ${ }^{13}$ In turn, in the German-speaking realm, one could find words such as Bauchsorge, Bauchdiener, or Bauchpriester, known from Luther's famous preface to The Large Catechism ${ }^{14}$ or the songs of Hans Sachs..$^{15}$ Owing to Luther's tremendous influence on the language of both Protestant and Catholic theology, these expressions became a permanent feature of theological vocabulary. ${ }^{16}$ Particularly following Luther's marriage to Katharina von Bora in 1525, Catholic polemics and pamphlets accused the Wittenberg professor of succumbing to the influence of the "belly," occasionally applying extremely vulgar language. ${ }^{17}$

11 N. Istasse, "Les Gingolphi de J. Ravisius Textor et la pseudohutténienne conférence macaronique," Humanistica Lovaniensia 6o (2011) 85-97; C. Postel, Traité des invectives au temps de la Réforme (Paris: Les Belles Lettres, 2004); E. Picot, Les moralités polémiques ou la controverse religieuse dans l'ancien théâtre français (Genève: Slatkine Reprints, 1970) 33-39.

12 Rabelais, Pantagruel, ed. P. Michel (Paris: Librairie Générale Française, 1972) 180; Gérard Defaux, Rabelais agonistes: du rieur au prophète: études sur Pantagruel, Gargantua, Le Quart Livre, (Genève: Droz, 1997) 476; Bruce E. Hayes, Rabelais's Radical Farce. Late Medieval Comic Theater and Its Function in Rabelais (New York: Routledge 2016) 99-139.

13 Mikhail Bakhtin, Rabelais and His World, tr. Hélène Iswolsky (Bloomington: Indiana University Press, 1984); see also Silvia Sasse, Michail Bachtin zur Einführung (Hamburg:JuniusVerl., 2010); Tina Ebbing, Körpermitte: eine Kulturgeschichte des Bauches seit der Frühen Neuzeit (Frankfurt/Main: Campus-Verl., 2008).

14 M. Luther, "Deudsch Catechismus (Der Große Katechismus, 1529)" in wA 30: 1, 125: "Die weil wir sehen, das leider viele prediger und pfarher hieryn seer seumig sind und verachten beide yhr ampt und diese lere, ettliche aus grosser, hoher kunst, ettlich aber aus lauter faulheit und bauch sorge"; comp. Albrecht Peters, Kommentar zu Luthers Katechismen, hrsg. von G. Seebaß, vol. 3 (Göttingen: Vandenhoeck \& Ruprecht, 1992) 83-87.

15 H. Sachs, "Ein geistlich Lied wider die Bauchsorge" in Hans Sachs ausgewählte poetische Werke, hrsg. von K. Pannier (Leipzig: Reclam, 1898) 32 [30].

16 See "Bauch" in Schlagwörter des Reformationszeitalters, hrsg. von F. Lepp (Leipzig: Heinsius, 1908) 131-134.

17 Ch.P.M. Burger, "Der Bettelmönch wird Ehemann-Wahrnehmungen und Polemik im 16. Jahrhundert" in Luther: Zankapfel zwischen den Konfessionen und "Vater im Glauben"? Historische, systematische und ökumenische Zugänge, hrsg. von M. Delgado, V. Leppin (Stuttgart: Kohlhammer, 2016) 29-52 (30-33); Th.A. Fudge, "Incest and Lust in Luther's 
Erasmus did not seem to attach any great weight to the neologism he had coined. The humanist did not use it in Antibarbari or The Praise of Folly. Neither did the term appear in the most scalding attack on scholastics: The Letters of Obscure Men, published anonymously in 1515, although, on the face of it, the expression would suit the tone of the work, and literally hung in the air. ${ }^{18}$ The biting satire penned by humanists impersonating obscure scholastics was based on juxtaposing the epistolary style prescribed in rhetorical textbooks with crude language, meaning not only dog Latin, but also a predilection for obscenities, words denoting excrement, miction and defecation, and intimate body parts making up the entire "realm of the belly."19

However, in the early sixteenth century, the expression was definitely known to humanists and followers of Erasmus, who used it in their private and unpublished correspondence. In 1512, it was employed by Johannes Altenstaig, a humanist and theologian educated in Tübingen, who would soon turn into an opponent of the Reformation. ${ }^{20}$ In his epistolographic treatise published in Augsburg, he employed the word theologastri in order to refer to theologians from Tübingen who either did not know Latin or used its barbarized form. ${ }^{21}$ Nevertheless, in his work Vocabularius theologiae from 1517, a sort of glossary

Marriage: Theology and Morality in Reformation Polemics," The Sixteenth Century Journal 34 (2003) 319-345 (334-344).

18 ASD IV-3: 148-152; WA-B, 1, 63, Nr. 25, M. Luther to G. Spalatin [October 1516] ("Porro misit ad me Prior Erfordensis Johan. Langus supplicationem contra theologastros, quae cum nihil gestae veritatis contineant, eundem vel similem histrionem sui testantur autorem, quam et Epistolae obscurorum virorum").

19 For further references see R.P. Becker, A War of Fools: the Letters of Obscure Men. A Study of the Satire and the Satirized (Bern: Lang, 1981) 85-106, 175-179; see also Erika Rummel, The Case against Johann Reuchlin: Religious and Social Controversy in Sixteenth-Century Germany (Toronto: University of Toronto Press, 2002) 14-35; D. Ménager, "Erasmus, the Intellectuals, and the Reuchlin Affair" in Biblical humanism and scholasticism in the age of Erasmus, ed. E. Rummel (Leiden: Brill, 2008) 39-54.

$20 \quad$ Friedrich Zoepfl, Johannes Altenstaig. Ein Gelehrtenleben aus der Zeit des Humanismus und der Reformation (Münster in Westf.: Aschendorff, 1918).

21 Johannes Altenstaig, Opus pro conficiundis epistolis, (Hagenau: Gran, 1512) fol. 57 $7^{\mathrm{r}}$ : "Arenga quod theologastri utuntur pro principio, exordio, initio," $59^{\text {r: }}$ "Commodosus vocabulum barbarum, quod a theologastris Tubingensibus persaepe audivi, quibus latinitas et elegans sermo est exitialis, etsi in aliis sint docti," $64^{\mathrm{r}}$ : "A nullo audivi, quam a theologastris, qui nullum cum latina lingua habent commercium." See J.N. Pendergras, "Humanismus und Theologie in Johannes Altenstaigs Opus pro conficiundis epistolis (1512)" in Germania latina —Latinitas teutonica, hrsg. von E. Keßler, H.C. Kuhn, vol. 1 (München: Fink 2003) 273-285. 
of scholastic theology that he dedicated to Johann von Staupitz and where he mostly invoked Duns Scotus, Jean Gerson, and Johannes Reuchlin, Altenstaig avoided the expression. ${ }^{22}$

The second humanist using the Erasmian term was Johannes Eck, a theologian and lecturer from Ingolstadt, who was to become the most prolific Catholic polemicist opposing Luther. On the eve of the Reformation, during the disputation on usury (so-called Zinsstreit), he defended this praxis, which led to him being called the lackey of the Fuggers, prominent family of financiers and bankers. ${ }^{23}$ Since the bishop of Ingolstadt had put a formal stop to the dispute, Eck's treatise was aimed against pseudo-literate advisors to bishops and other theologasters. ${ }^{24}$

The intense print activity of the Reformation introduced new insults. Both sides of the conflict—-defenders of the Curia and Protestants-soon recognized Erasmus' term. The first people to adopt his expression were two fierce polemicists: Eck and Martin Luther. Already around 1518-in the first disputation concerning Luther's Theses ${ }^{25}$-Eck accused semi-literates and theologasters of meddling in theology. ${ }^{26}$ Since Eck had titled himself Obeliscus, Luther responded under the pseudonym Asteriscus. In his opinion, Eck and "all his scholastic theologasters" (ab universis suis theologastris scholasticis) were not able to counter any arguments against indulgences. ${ }^{27}$ Both sides of the dispute were hurling the same epithet at each other. In the writings of the polymath and humanist Eck, pseudo-theologians denoted followers of the Ref-

22 Johannes Altenstaig, Vocabularius Theologie complectens vocabulorum descriptiones, diffnitiones et significatus ad theologiam vtilium (Hagenau: Gran, 1517) fol. $253^{\mathrm{r}}$ : "Et theologia a divina locutionem sumpsit vocabulum, ut scribit Joannes Reuchlin ille doctissimus in sua defensione contra quibusdam theologos, qui et ibidem ponit differentia inter theologum et theologistam." Comp. also a more popular edition: Idem, Compendium vocabularii theologici scholastici (Parisiis: Chaudière 1580).

23 Copies of the manuscript "Concilium Ioan. Eckii Theologi in casu quique de centenario" (11. August 1514) are stored in many libraries and archives, see Johann Peter Wurm, Johannes Eck und der oberdeutsche Zinsstreit 1513-1515 (Münster: Aschendorff, 1997) 221285. See also G.-R. Tewes, "Luthergegner der ersten Stunde. Motive und Verflechtungen," Quellen und Forschungen aus italienischen Bibliotheken und Archiven 75 (1995) 337-340, 348-349, 361-364.

24 Concilium, fol. $156^{\text {r: }}$ "semilitterati Episcoporum consules et alij quidem Theologastri."

25 David N. Bagchi, Luther's Earliest Opponents: Catholic Controversialists 1518-1525 (Minneapolis: Fortress Press, 1991) 188-201.

26 A reconstruction of Eck's manuscript in WA, 1, 278-314. A new edition in Dokumente zur Causa Lutheri, ed. P. Fabisch, E. Iserloh, vol. 1 (Münster: Aschendorff, 1991) 376-447.

27 "Asterisci Lutheri adversus Obeliscos Eckii" (1518) in WA, 1, 284 ("Deum autem imponere poenas peccatori confitenti nego, nec potest probari a nostro obeliscographo nec ab universis suis Theologastris scholasticis"). 
ormation. In turn, Luther used the term in its meaning coined by Erasmus at the turn of the century, accusing "certified" theologians of incompetence and arrogance.

At the same time as launching his polemic against Luther, Eck wrote a letter to Erasmus, praising the supreme erudition that had won him general respect. According to Eck, everyone was an Erasmian apart from a narrow group of monks and theologasters. ${ }^{28}$ Trying to encourage Erasmus to dissociate himself from Luther and Wittenberg, Eck assured the humanist that Erasmians would protect him against theologasters. ${ }^{29}$

The fact that both Luther and Eck used the term in a slightly different meaning could be the reason why Erasmus rarely used the neologism he had invented. However, he did remind his followers about it between 1518 and 1521, when he published selected correspondence containing his letters to Grey and Eck's missive. ${ }^{30}$ Simultaneously, he decided to include the neologism into a new edition of Adagia, published in Basel in $1515 .^{31}$ Some of his readers and supporters-like a suffrage bishop of Speyer, Anton Engelbracht in his copy of Erasmus' edition of Jerome ${ }^{32}$-placed the word theologaster on the margins of Erasmus' writing as synonym for a scholastic theologian.

At the time, following the first edition of the New Testament, the humanist was at the peak of his fame. ${ }^{33}$ However, the growing popularity of Martin

28 Ep. 769 Allen lines 20-25: "Non enim te latet, mi Erasme, quam bene de te sentiat omnis Germania (obticeo summum Pontificem, Italiam, Galliam et Angliam), quibus laudibus tua efferat studia, ingenii tui excipiat foeturas, praeclara exosculetur opera; ut omnes ferme docti prorsus sint Erasmiani, cucullatis paucis demptis et theologastris." See also a digital edition of Eck's correspondence by Vinzenz Pfnür: http://ivv7srv15.uni-muenster .de/mnkg/pfnuer/Eckbriefe/Eck-Briefe.pdf.

29 Ibidem, lines 33-34: "Nam et sic Erasmici tui melius adversus theologastros te defensabunt, et tuipse magnum tibi adieceris gloriae et decoris ornamentum."

30 Auctarium selectarum aliquot epistolarum Erasmi Roterodami ad eruditos (Basileae: Froben, 1518) fol. 39-44; Farrago nova epistolarum Des. Erasmi Roterodami (Basileae: Froben, 1519) fol. 169-171; Epistolae D. Erasmi Roterodami ad diversos et aliquot aliorum ad illum, per amicos eruditos, ex ingentibus fasciculis schedarum collectae (Basileae: Froben, 1521) fol. 106-108.

31 ASD II-2: 388: "Id adagionis hac tempestate nimis ridicule usurpatur a philosophastris istis ac theologastris, si quando Latinae Graecaeque linguae inscitia foedissime labuntur, quod fere nusquam non faciunt."

32 C.H.W. van den Berg, "Die Glossen von Anton Engelbrecht in der Hieronymusausgabe des Erasmus und ihre Bedeutung," Nederlands archief voor kerkgeschiedenis 67 (1987) 29: "In theologastros nostros peripateticos."

33 Christoph Galle, Hodie nullus — cras maximus: Berühmtwerden und Berühmtsein im frühen 
Luther and Protestant ideas exposed Erasmus to ever-more vocal accusations concerning his ties to the reformer and the fledgling Lutheranism. The humanist was attacked by Edward Lee (disputation began in 1518), Jacob Stunica (d. 1531, disputation in 1522), Petrus Sutor (Pierre Cousturier), Noël Beda (15251526), and Albertus Pio (1529). ${ }^{34}$

Again, the Erasmian neologism hung in the air, even if the theologian himself used the expression sparingly. One of Erasmus' apologies against Edward Lee was printed in 1520 together with a poem by Riccardo Sbruglio against some sycophantic theologasters from Louvain. ${ }^{35}$ The invective appeared, however, only on the title page of the print and not in the poem itself, which defended divine or angelic Erasmus against his unworthy opponent, whom the author compared to a barking but tailless and snoutless dog. In his defenses against accusations of harboring sympathy for Protestantism, Erasmus had to deny his alleged aversion to Catholic theologians whom he had dubbed theologasters. In his Apologia addressed to the canon of Calahorra, Sancho Carranza de Miranda (d. 1531), who in 1522 invited the humanist to debate, encouraging him to dispel any doubts concerning his attitude, Erasmus claimed to have never employed the term theologaster with respect to theologians. ${ }^{36}$ Further on in the work, he specified that even if he had ever used this expression, it would

16. Jahrhundert am Beispiel des Erasmus von Rotterdam (Münster: Aschendorff, 2013) 20, 171-203, 306, 366-367; V. Sebastiani, "The Impact of Erasmus' New Testament on the European Market (1516-1527): Considerations Regarding the Production and Distribution of a Publishing Success" in Basel 1516: Erasmus' edition of the New Testament, ed. M. Wallraff, S. Seidel Menchi, K. von Greyerz (Tübingen: Mohr Siebeck, 2016) 225-238.

34 ASD IX-9; CWE 72, 73, 75, 84. About these controversies see Robert Coogan, Erasmus, Lee and the Correction of the Vulgate: the Shaking of the Foundations (Genève: Droz, 1992); Grantley McDonald, Biblical Criticism in Early Modern Europe: Erasmus, the Johannine comma, and Trinitarian Debate (New York, NY: Cambridge University Press, 2016) 1356 .

35 Apologia Erasmi Roterodami palam refellens quorundam seditiosos clamores apud Populum ac Magnates, quibus ut impie factum iactitant, quod in euangelio Ioannis verterit, In principio erat sermo. Carmen Ricardi Sbrulii poete Caesarii, in quosdam Theologastros Louanienses Sycophantas, extemporale (Nuremberg: F. Peypus, 1520). The Apology is edited in CWE 73: 3-12 without the poem; Denis L. Drysdall assumes (ibidem, xli) the work was published in Basel (Froben), Antwerp (Hillen), Cologne (Cervicornus), Leuven (Martens), Nuremberg, and Mainz (Schöffer). I could identify only the Nuremberg edition.

36 ASD IX-8: 34: "Ac rursum: theologorum, inquit, nostrorum, quos ipse theologastros solet vocitare. Ego sane nec passim, nec quosvis theologos sic appello." See Sancho Carranza de Miranda, Opusculum in quasdam Erasmi Roterodami annotationes (Romae, 1522) A2. About the controversy, see A. Coroleu, "Anti-Erasmianism in Spain" in Biblical Humanism $79^{-81 .}$ 
have been aimed against conceited schoolmen who ignored the Scriptureabove all against the Sorbonne, and not against any true experts in divine affairs. ${ }^{37}$

The second example is his disputation from 1525 with the Carthusian Petrus Sutor, where Erasmus defended the right of laypersons to read and interpret the Bible. ${ }^{38}$ The humanist was provoked by Sutor, who claimed in his work $D e$ tralatione Bibliae (1525) that the laity had no right to analyze the Holy Scripture. The Bible, a difficult and mysterious book, could only be explored by experts with adequate skills and time. It should not be touched by uneducated people, women, and theologastri (quos antichristipraecursores vocant), who dare to not only paraphrase the New Testament but also prepare revised translations thereof. ${ }^{39}$ This was a clear and unambiguous attack on Erasmus and Jacques Lefèvre d'Étaples using their own rhetorical weapon. Erasmus responded in the same year with Apologia adversus Petri Sutoris debacchationes, claiming that the Bible had been written in the language of ordinary people and addressed to them. ${ }^{40}$ To Sutor, claimed Erasmus, sumus omnes theologastri, although the humanist tried to prove that it was in fact the Carthusian who was lacking eloquence.

37 ASD IX-8: 80: "An quod alicubi dixerim theologastros? Id Sanctius ita subinde ingerit, ad mihi conflandam invidiam, quasi omnes theologos scholasticos appellem theologastros. Imo si quando noto istos qui, sophisticis aliquot argutiis freti, sibi magni videntur theologi, quum nihil teneant in Sacris voluminibus, ideo theologastros appello, ne boni theologi putent se notari. At subinde Sorbonae nomen inculcat, quasi damnentur à me Sorbonici theologi."

38 About this polemic, see R.M. Cameron, "The Charges of Lutheranism brought against Jacques Lefevre d'Etaples," Harvard Theological Review 63 (1970) 119-149; W. François, "Petrus Sutor et son plaidoyer contre les traductions de la Bible en langue populaire (1525)," Ephemerides Theologicae Lovanienses 82 (2006) 137-161; J.K. Farge, "Noël Beda and the Defense of the Tradition" in Biblical Humanism 143-164; M. Crane, "A Scholastic Response to Biblical Humanism: Noël Beda against Lefèvre d'Etaples and Erasmus (1526)," Humanistica Lovaniensia 59 (2010) 55-81.

39 Petrus Sutor, De tralatione Bibliae, et novarum reprobatione interpretationum (Parisiis: Parvus, 1525) fol. A2 ${ }^{r}$; fol. XCIX r-v: "Ipsorum quoque theologastrorum annotationes sive commentarios, ymo vero paraphrases nullo modo legat vel attingat, nisi adeo sit theologicis literis imbutus ut haereses a veritatibus catholicis discernere possit."

40 ASD IX-9: 174-180. 
Erasmus' neologism quickly made it to printed works and became firmly established therein. In the first years of the Reformation, the term theologastri was employed by some of the most eminent theologians across all the Protestant movements, such as Ulrich Zwingli, ${ }^{41}$ Jean Calvin, ${ }^{42}$ and Theodore Beza. ${ }^{43}$ One of the most widely read and impactful works was a textbook of Lutheran theology, first published in $15^{21}$ by Philip Melanchthon as Loci communes. In the chapter on free will and the power of sin, Melanchthon noted that humans were not free at all, and scholastic interpretations obscured the meaning of Grace, Right, and the Gospel. This pitch-darkness was due to the "philosophy of the Scholastic theologasters." ${ }^{4}$ Apart from the well-known passage from Loci, which was studied at every Lutheran faculty of theology in the first half of the sixteenth century, one could point to several other examples of Melanchthon's use of Erasmus' expression in correspondence and less important letters. ${ }^{45}$

The most notable deployments of the Erasmian term were Melanchthon's polemics and Luther's defense against the Sorbonne's judgment. In the first disputation, published by Melanchthon in 1521, the humanist replied to a Roman criticism penned by the Dominican Tommaso Rhadino (Thomas Radinus Placentinus, 1490-1527). ${ }^{46}$ Rhadino's polemics contained a widely held catalogue of accusations against Luther, who dared to undermine authorities of the Church, repeating the mistakes of condemned heretics such as Wycliffe and Hus. Owing to the certain conventionality of these attacks, Wittenberg circles assumed the author to be one of the earlier polemicists (e.g., Hieronymus

41 "De canone missae epichiresis" in Huldreich Zwinglis sämtliche Werke, hrsg. von Emil Egli, Georg Finsler, vol. 2 [Corpus Reformatorum, vol. 89] (München: Kraus, 1981) 594.

42 J. Calvin, "Pro G. Farello et collegis eius adversus Petri Caroli theologastri calumnias defensio Nicolai Galasii" in Ioannis Calvini Opera quae supersunt omnia, ed. G. Baum, E. Cunitz, E. Reuss, vol. 8 [=Corpus Reformatorum, vol. 89] (Brunsvigae: Schwetschke, 1863) 289-340. Theodore Beza, Apologia Th. Bezae Vezelii, ad libellum Sorbonici Theologastri F. Claudii de Xaintes, cui titulum fecit, Examen Calvinianae \& Bezanae doctrinae de Coana Domini ex scriptis authorum eiusdem collectum (Genevae: Jean Crespin 1567).

"Loci Communes rerum theologicarum seu hypotyposes theologicae" (1521) in Corpus Reformatorum, vol. 21, ed. H.E. Bindseil, 115: "Et has tenebras plusquam Aegyptias debemus impiae isti et execrabili scholasticorum Theologastrorum philosophiae."

See Philipp Melanchthon to Georg Spalatin, Wittenberg, October 1522 in Corpus Reformatorum, vol. 1, ed. K.G. Bretschneider, 218, 579: "De rebus papisticis non ita multa dixit. Hunc unum attigit locum, iudicium doctrinae esse apud eos, quibus Spiritus Christi sit; atque in eo aliquantisper immoratus est propter theologastros Erphurdienses, qui excludunt a iudicandi provincia eos, qui Aristotelem non didicerunt." 
Emser), with the result that Melanchthon would also publish his reply under a pseudonym, as Didymus Faventinus. ${ }^{47}$

Melanchthon structured his apology around five main points concerning scholasticism, the obligations of secular authority, indulgences and penance, the war with the Ottoman Porta, and papal authority. Invoking, among others, Pico della Mirandola - and implicitly referencing the works of many other humanists-Melanchthon painted scholasticism as dark and rotten. ${ }^{48}$ His most serious allegation against it was the subordination of theology to philosophy, forgetting about the Bible in the process. The scholastics treated Aristotle, whom they uncritically worshipped, ${ }^{49}$ as their undisputed authority, and the science they pursued represented childish tomfoolery, frivolous questions and stupid opinions. ${ }^{50}$ Recalling the dispute concerning the Donation of Constantine, signing over authority over Rome and the western empire to the Pope, and Lorenzo Valla's work in proving it a forgery-reissued on the initiative of the Protestants and hotly debated in Wittenberg ${ }^{51}$ - Melanchthon criticized papal authority and the concept of apostolic succession. ${ }^{52}$ Seemingly in line with Luther's beliefs, he argued that the two regimens - matters of faith and earthly politics—should be separated, making several references to Luther's work On the Babylonian Captivity of the Church. At the same time, however, he urged secular authorities to embark upon reforms, above all in the sphere of education and the academy, where scholastics had wreaked the greatest havoc, promoting insatiable greed, arrogance, obstinacy, and hubris—in other words, "what the Turk cannot accomplish, we accomplish ourselves." ${ }^{23}$ And so, despite the sim-

47 Didymi Faventini adversus Thomam Placentinum Oratio pro Martino Luthero Theologo (Wittembergae: [Lotter], [1521]) edited in Corpus Reformatorum, vol. 1, 286-358; for a modern edition see Melanchthons Werke in Auswahl, hrsg. von R. Stupperich, vol. 1 (Gütersloh: Bertelsmann, 1951) 56-140.

48 Didymi Faventini adversus Thomam Placentinum Oratio, 319-320.

49 Ibidem, 305: "I nunc, Hirce, et nega, Idolatriam esse scholasticem doctrinam, cui tam varias, tam absurdas de deo opiniones debemus" and 306: "Non hic periculum accuso, sed praesentem calamitatem deploro, quae eiusmodi est, ut multo minore rerum Christianarum damno interim vel Maxentii vel Diocletiani, qui in Ecclesiam ferro desaeviere, regnasse videri possint, quam regnarunt doctorculi isti, qui nova docendi ratione reperta Evangelium obliterarunt, Christo e simplicium animi revulso, Aristotelem inseruere."

50 Ibidem, 344: "Porro mihi consideranti paulo attentius scholasticam istam, quam vocant, Theologiam, praeter pueriles nugas, frivolas quaestiones, stultas opiniones plus errorum docere videtur, quam ulla unquam haeresis adeoque in universum nihil aliud esse scholastica doctrina, quam impudentes blasphemiae adversus veritatem Evangelii."

51 D.M. Whitford, "The Papal Antichrist: Martin Luther and the Underappreciated Influence of Lorenzo Valla," Renaissance Quarterly 61 (2008) 26-52.

$5^{2}$ Didymi Faventini adversus Thomam Placentinum Oratio, 340.

53 Ibidem, 345: "Odia in nullo genere sunt acerbiora, quam in Academiis. Avaritia inex- 
ilarity to Luther's thought, by calling upon lay authorities to reform academia and the Church, and comparing princes to the Old Testament kings Hezekiah and Josiah, Melanchthon in fact contradicted Luther's appeal to divide the two domains, leaving lay authorities an open path to intervening in matters of the Church. ${ }^{54}$

On several occasions in his disputation, Melanchthon referred to scholastics and bishops supporting Rome's authority as theologasters. ${ }^{55}$ In the context of his comprehensive attack on scholasticism, this term had a deeply Erasmian significance: denoting pseudo-theologians who had forgotten about the Bible - the genuine foundation of theology, and about classical culture, which made it possible to interpret the Scripture. However, among his accusations hurled at scholastics who had taken control of universities, there were also ones known from reformatory polemics: that schoolmen only cared about "their bellies." ${ }^{56}$ Consequently, Roman "inventions" — such as indulgences or sacramental mass - only served to "fill the bellies" of employees of the Church. ${ }^{57}$ The belly signified first and foremost concern for one's personal interests, income, position, and earthly authority. ${ }^{58}$ Nevertheless, in line with the Epistle to the Philippians quoted by Melanchthon (Phil. 3:19), it was also used as a synonym for sin in general.

plebilis, supercilium, tumor et fastus, quantus alius nusquam. Et talibus exemplis cogitare non potestis, quid promoveat adulescentia, quae Academiis committitur. Et huiusmodi quidem sunt scholae, quas ne Turci quidem ferant, nos ferimus, quia Papae, immo Satanae inventum sunt."

54 Ibidem, 357: "Proinde Principes, quaeso, Evangelii maiestatem salvam velitis et ab illis Pseudochristis doctoribus Theologastris et Antichristi Romani tyrannide reliquias Ecclesiae fortiter vindicetis." James Estes, Peace, Order and the Glory of God: Secular Authority and the Church in the Thought of Luther and Melanchthon: 1518-1559 (Leiden: Brill, 2006) $59 \mathrm{f}$.

55 Didymi Faventini adversus Thomam Placentinum Oratio, 295, 311, 322-323, 343.

56 Ibidem, 291: "qui ventri suo male metuebant," 292: "Et favebant insanis hominis conatibus ferocientes fraterculi, scholastici Theologi, adeoque examen illud perditorum hominum, quod a Rhadino stare videtis, alii ventris, alii gloriae suae periculum prospicientes, nisi vinceret Eccius," 293: "qui ventri suo gloriaeque male metuebant," and 297: "male metuere ventri suo."

57 Ibidem, 350: "Missa quaestui habetur, sacrosanctum domini corpus foedissimos ventres alit."

$5^{8}$ Ibidem, 323: "Si Christianos faciunt, Theologastri, purpura, mitra, tituli vestri et illa insana stipendia, quibus saginamini, nihil Christianius reperiemus Sybaritis illis ac Milesiis hominibus, ut ferunt, prodigiosae luxuriae." 
In the same year, Melanchthon re-employed some of these arguments, including the term theologasters, in his apology against the Sorbonne's verdict of 15 April 1521, which concerned, among others, the Leipzig disputation of $1519 .{ }^{59}$ According to the Sorbonne, the debate was won by Eck, and some of Luther's statements, particularly those contained in his work On the Babylonian Captivity of the Church, were deemed heretical. Melanchthon argued against the judgment, claiming that the Sorbonne theologians were in fact sophists defending their own science and dogmas. On the other hand, Luther's views were not just in line with the Bible but also with the writings of ancient church fathers: Augustine, Cyprian, and Ambrose. Consequently, defending Luther against the Sorbonne's verdict was meant to prove that the Wittenberg scholar was an authentic theologian, while the "Sorbonne masters" merely gave off the appearance of theological competence-they were theologasters rather than true theologians. Subsequently, the Theologasters, "who were blinded by self-love and Pharisaic righteousness," became regular objects of the Protestant defenses against the verdict of the Sorbonne. ${ }^{60}$

Perhaps it was the impact of Melanchthon's Apologia that led Jean Calvin and Theodore Beza to employ the Erasmian term in their later confessional polemics, for instance on the dispute concerning the Augsburg Interim (1548) ${ }^{61}$

59 Adversus furiosum parisiensium theologastrorum decretum, Philippi Melanchthonis pro Luthero Apologia (Vittenbergae: Lotter, 1521) editied in Corpus Reformatorum, vol. 1, 398416; a German translation in WA, 8, 295-312.

6o Confutatio Determinationis Doctorum Parrhisiensium, contra M.L. ex Ecclesiasticis doctoribus desumpta, denuo recognita et locupletata. Adiecta est Disputatio Groningae habita (Basilae, 1523) fol. a2v: "Quoniam Parrhisiensies Theologastri non potuerunt in lucem veritatis oculorum aciem intendere, quae per Mar. Lutheri spiritum toti illuxit orbi, qui sui amore et pharisaica sua iustitia occaecati essent, idque Aristotelis beneficio, quam ipsi numinis cuisdam loco haben, pro virile parte eorum deploratam caliginem, pro charitatis officio miserati, in hoc incumbuimus." Published in Bibliotheca reformatoria Neerlandica, vol. 6, Geschriften van Joann. Puppervan Goch en Corn. Grapheus; Confutatio determinationis Parisiensis contra M.L., ed. F. Pijper ('s-Gravenhage: Nijhoff, 1910) $578-583$. The authorship of the anonymous apology remains unknown, see wA, 8, 265-266. The attached files of disputation of Groningen (1523) and some stylistic similarities drew the attention of some scholars to the humanist Hendrik van Bommel, but the attribution is still doubtful. See F.S. Knipschee, "Hendrik van Bommel schreef 'Confutatio ...' 1521," Nederlands archief voor kerkgeschiedenis, Nieuwe Serie 32 (1941) 171-195; P.F. Wolfs, Das Groninger 'Religionsgespräch' (1523) und seine Hintergründe (Nijmegen: N.V. Dekker, 1959) 2-6.

61 J. Calvin, "Interim Adultero-Germanum" (1549) in Opera Calvini, vol. 7 [Corpus Reformatorum, vol. 35], 6o4: "Antehac Sorbonicis theologastris propter crassam inscitiam poterat ignosci, quum [!] scripturam perperam corrumperent. Nunc in tanta luce non eadem 
When, in the mid-sixteenth century, Calvin published the apology of his collaborator from Geneva, Guillaume Farel, against Pierre Caroli's accusations, the term was included in the title of these works. ${ }^{62}$ At the time, the expression theologasters was most frequently used with respect to Parisian theologians-i.e., the Sorbonne. ${ }^{63}$

In France, the term owed its fame to farces which were much more popular than the theological treatises. A crucial work stigmatizing Parisian theologians was La Farce des Théologastres - a dialogue written in France during the period of confessional disputes. ${ }^{64}$ Like many works from the era, it was published anonymously, without the printer's name or place of publication, but may be assumed to have been printed in Lyon, most likely in the printing shop of Barnabé Chaussard, between 1532 and $155^{2} \cdot{ }^{65}$ However, the moment of publication does not correspond to the date of creation, as the farce must have been written a long time beforehand. Dating this work to the 1520 is supported by its connection to the trial of Louis de Berquin (1490-1529), the translator of Erasmus' and Luther's works. The trial was definitively concluded on 17 April 1529, when Berquin was burned at the stake, but the work was most likely created between November $15^{26}$ and June 1528 , when the translator and his supporters (including Erasmus) were still fighting for his acquittal. ${ }^{66}$

valere debet excusatio"; ibidem, 666: "Est hic Robertus, de quo loquor, vetulus Sorbonae theologaster, et episcopus Abrincensis. Cogitabam equidem homines minus sani cerebri senio non deliros reddi tantum, sed aliquanto etiam morosiores." About the debate on the Interim in Switzerland and in France see Th. Maissen, "Die Eidgenossen und das Augsburger Interim. Zu einem unbekannten Gutachten Heinrich Bullingers" in Das Interim: Herrschaftskrise und Glaubenskonflikt, hrsg. von Luise Schorn-Schütte (Gütersloh, 2005) 76-104 and G. Chaix, "Die Resonanz auf das Interim in Frankreich 1548-1598" in ibidem, $67-75$.

62 Jean Calvin, Défense de Guillaume Farel et de ses collègues contre les calomnies du théologastre Pierre Caroli par Nicolas Des Gallars, ed.J.-F. Gounelle (Paris: PUF, 1994); Pro G. Farello et collegis ejus adversus Petri Caroli theologastricalumnias defensio Nicolai Gallasii, ed. Olivier Labarthe (Genève: Droz, 2016); an older edition as "Pro G. Farello et collegis eius adversus Petri Caroli theologastri calumnias defensio Nicolai Galasii," in Opera Calvini, vol. 7 [Corpus Reformatorum, vol. 35], 289-340.

63 See Apologia Th. Bezae Vezelii, ad libellum Sorbonici Theologastri F. Claudii de Xaintes, cui titulum fecit, Examen Calvinianae \& Bezanae doctrinae de Coana Domini ex scriptis authorum eiusdem collectum (Genevae: Jean Crespin, 1567).

64 La farce des Théologastres, ed. C. Longeon (Genève: Droz, 1989).

65 See Clémence Miellet, Barnabé Chaussard et ses successeurs: 1492-1560, [2014], 25, 54, 13 https://www.enssib.fr/bibliotheque-numerique/documents/64121-barnabe-chaussard-etses-successeurs-1492-156o.pdf [access: 18 Januray 2021].

66 For the details see C. Longeon, Introduction in La farce des Théologastres, 9-13. About the trial see Registre des procès-verbaux de la faculté de théologie de l'université de Paris de jan- 
Apart from the title's Theologasters, other protagonists of the farce include Brothers (Fratres), Faith (Foy), Reason (Raison), Scripture (Le Texte de saincte Escripture), and Mercury from Germany (le Mercure d'Allemaigne). The play is composed of four parts: in the first, Faith talks to Theologasters and Brothers; in the second, the debate is joined by Reason and Scripture; in the third, Reason and Scripture visit Mercury; and in the fourth, Mercury, Reason, and Scripture revisit Theologasters, Brothers, and Faith.

The farce begins with a disease to which Faith has succumbed. ${ }^{67} \mathrm{Her}$ complaints interrupt a scholarly dispute between Theologasters and Brothers about the misery of the "new theologians" (theologiens noveaulx), who despise scholastic Latin and read only Greek (omnes nunc leguntur [!] grecum). ${ }^{68}$ In turn, Faith is suffering from colic caused by sophistry (passïon sophisticque), from the simony that ruined her reputation (Simonie la pthisique / M'a du tout mon bon bruit tolly), and from the spread of unbelief (une mode lunatique). In a nutshell, she is plagued by le mal sorbonique. However, to Brothers' and Theologasters' horror, the cure to Faith's problems is to be found in Germany-the homeland of Martin Luther. And, rather than convening councils or celebrating "Judaic ceremonies" (judaïque ceremonie), it involves reading the Holy Scripture. Obviously, this is something Brothers and Theologasters cannot agree with, as they find the Scripture unclear, attaching greater weight to the authority of Parisian theologians. ${ }^{69}$ At this moment, the dispute is joined by Reason and Scripture, both of which find holes and inconsistencies in the arguments employed by Noz Maistres Theologastres, criticizing their pursuit of profit, their greed, and their conspiracy against translations of German literature.

It is in this context that the name of Louis de Berquin first appears in the text, but he is only mentioned as a translator of Erasmus' oeuvre from Latin into French, not as an expert in the writings of Martin Luther, which were also published in German. Reason also alluded to the heresy trial instigated against

vier 1524 à novembre 1533, ed. J.K. Farge (Paris: Aux Amateurs de Livres, 199o) n. 94a, 95a, 145a; J.K. Farge, "Les procès de Louis de Berquin: épisodes dans la lutte du Parlement de Paris contre l' absolutisme royal," Histoire et Archives 18 (2005) 49-77.

67 See Jonathan Beck, Théâtre et propagande aux débuts de la Réforme (Genève:Slatkine 1986) 122.

68 The passive voice is probably an intentional grammatical mistake.

69 Such as John Major, Alexandre de Halés, Guillaume Durand, Egidio Colonna, Pierre Renaudin, Thomas Bricot, Jerôme de Hangest, Richard of Middleton, Meffreth von Meissen, Gabriello Barletta, Giacomo de Varragio (Jacobus de Voragine), Jacques Almain, Robert Holkot, Jean Lescot or Johann Nider (La farce, lines 104-115). Faith wanted to put Jean Gerson on the list, but he was rejected by the Theologastres "car c'est ung malvis papaliste" (ibidem, line 123). 
de Berquin without the presentation of any reasons by the prosecution (sans monstrer erreur ne raison). Scripture, on the other hand, complained that no one gave the Bible as much attention as Erasmus, Melanchthon, and Faber (i.e., Jacques Lefèvre d'Étaples). In the world of Parisian theologians, one's position depended on criteria other than cause or reason: abstract argumentation skills (tout leurs queros et utruns) and giving feasts (Si on veult estre bien disné, / Il convient en leurs actes estre). Further on, Reason and Scripture started listing the mistakes committed by theologians from Paris: not only did they neglect reading the Bible because of their focus on scholastic methods, but they also prevented laypersons from accessing the book. Their lectures were little more than absurd tricks and follies (plus folles tricques) where the works of Aristotle were more important than the Bible, so they deserved to be called Theolonginqui. ${ }^{70}$ Since their focus revolved around questions of whether God knew how many fleas there were in Paris or whether God could be a woman, an animal, or a stone, they turned into targets of jokes and mockery.

As the debate was nowhere near a conclusion, Reason and Scripture sought the help of Mercury from Germany, with whom they returned to the sick Faith, Theologasters, and Brothers. Mercury introduced himself as "Berquin," but—on seeing him—Brothers shouted "Lutherïn," to which Mercury-Berquin retorted: Nenni non, je suis chrestien! ${ }^{71}$ When Theologasters declared that Erasmus, Faber, Luther, and Berquin were nothing more than heretics to them (n'estes que garçons heretiques), Mercury-Berquin told them to stop their follies, tricks, and flatteries and instead point out where and how he was in the wrong. However, Theologasters did not allow the debate to turn into a rational exchange of opinions based on an analysis of texts, instead treating their own judgment as the basis of faith. In their eyes, this vindicated their arbitrary decisions and unjustified sentences. ${ }^{72}$ When Mercury-Berquin launched into a tirade in defense of reason (la raison), Faith told him to stop and start listening to her. Then, Mercury-Berquin embarked on a speech that may be seen as the conclusion and summary of the entire work. He suggested that Theologasters should look into a mirror (Speculum / Aultrement dit le grand Miroer / Des Theologastres) - i.e., de Berquin's work, currently presumed lost. Mercury-

70 See U.von Hutten, "Eccius Dedolatus" in Vlrichi Hvtteni Eqvitis Germani Opera Qvce Reperiri Potvervnt Omnia, ed. E. Böcking, vol. 4 (Lipsiae: Teubner, 1860) 517-543 (542).

71 Comp. R.M. Cameron, "The Charges of Lutheranism," 12of. For discussion of the term see Jonathan A. Reid, King's Sister-Queen of Dissent: Marguerite of Navarre (1492-1549) and her Evangelical Network (Leiden: Brill, 2009) 9-11.

72 "Il est dit, selon nostre loy, // Que nous, principes de la foy, // Povons tout dire sans rayson," La farce, lines 508-511. 
Berquin criticized indulgences, the idea of the mass as opus operatum, and the lenient piety of theologians from the Sorbonne. Promoting the idea of liberation from sin through indulgences in fact completely undermined the meaning of contrition and atonement. ${ }^{73}$ As Claude Longeon has convincingly claimed, this line of criticism was very close to ideas contained in Luther's Ablaßthesen, where the attack against indulgences began with exploring the meaning of a call to atonement. ${ }^{74}$ In the alternative presented by Mercury-Berquin (indulgences vs. contrition and penance), one may hear echoes of Thesis 39: "It is very difficult, even for the most learned theologians, at one and the same time to commend to the people the bounty of indulgences and the need for true contrition." ${ }^{75}$ Following these impudent declarations on the part of MercuryBerquin, the Farce experiences a similar slump as can be observed in Erasmus' Praise of Folly. The Brothers preferred to stay out of the debate, but ominously stated that they "[would] find Mercury" (Ne te chault, on te trouvera), while Reason concluded the farce with an Erasmian declaration: Everything was meant as a joke aimed at Theologasters and not theologians.

The message of this work follows the poetics of early Reformation debates. Sorbonne theologians were accused of rather stereotypical offences, known from polemic literature since the times of Petrarch, popularized in Northern Europe by The Praise of Folly or The Letters of Obscure Men, and also employed in polemics published by Melanchthon. The main and most serious argument against them was incompetence. On several occasions, Theologasters and Brothers admitted to having never read the Bible (this was symbolically conveyed in the scenes where they failed to recognize their interlocutorsScripture, Reason, and Mercury-Berquin); they did not know Latin, Greek, or Hebrew; they were against granting the faithful, particularly women, access to the Bible; and were the object of general mockery and ridicule. These faults were exacerbated by the virtues of Mercury-Berquin, who was educated, wise, and refined. He recognized Reason and Scripture straight away, and during the debate offered to provide Theologasters with translations of texts they were not able to understand. He also clearly declared openness to any rational argu-

\footnotetext{
73 "Sy indulgece la coulpe efface // Contritïon n' a d' efficace // Pas un grain; ou sy elle en a, // Rien ne vault ce mot a culpa // Contritïo delet culpam," La farce, lines 611-615.

74 C. Longeon, "Introduction" in La farce des Théologastres, 11.

75 M. Luther, "Disputatio pro declaratione virtutis indulgentiarum" in WA, 1, 235: "Difficillimum est etiam doctissimis Theologis simul extollere veniarum largitatem et contritionis veritatem coram populo." See Henri Strohl, L'Épanouissement de la pensée religieuse de Luther de 1515 à 1520 (Strasbourg: Istra, 1924) 219-223, 232. See also a comment by Luther "Indoctis vero, cum sit nihil 'difficile', nihil obstat, quin et hoc sit facile” in Walther Köhler, Luthers 95 Thesen samt seinen Resolutionen (Leipzig: Hinrichs, 1903) 132-134.
} 
ments put forward by his opponents: Se j'ay erré / Que on me demonstre mon erre, / A la fin de la corriger. Claude Longeon interpreted these words as an allusion to Martin Luther's speech at the Imperial Diet of Worms on 18 April $1521 .^{76}$ On this occasion, Luther refused to change his professed beliefs unless his adversaries convinced him by making recourse to either arguments from the Bible or rational reasoning. According to Joachim Knape, despite adhering to elements of the modesty topos, in Worms Luther intentionally and skillfully modeled himself on Jesus. ${ }^{77}$ The Christological image of the reformer was also emphasized in Passio Doctoris Martini Lutheri published in $1521 .^{78}$ This work unambiguously depicted Luther as Christ, which is important in the context of Mercury-Berquin comparing himself to Jesus in the farce.

This rather stereotypical critique of the clergy and theologians lacked at least one element employed in previous disputations and gave marginal importance to another. First of all, the moral decay of the clergy was entirely omitted: the farce features none of the usual jokes about priests living in informal relationships or the "monastic phallus."79 Controversial issues of the time, such as the tithe, the quest for profit, and accumulating prebends, were only mentioned in passing. In short, elements of popular humor referring to the "realm of the belly" were abandoned in favor of theological issues: the Bible's accessibility and laypersons' right to interpret it, ecclesiology, and soteriology. While there is no doubt about the humanistic and Lutheran character of the farce, there is no clear demand for access to communion under both species, the criticism of indulgences does not lead to expounding the idea of justifying sola fide, and making fun of the ecclesiological concepts put forward by Theologasters or the dogmas of the infallibility of the Church and popes gives no grounds for formulating the principle of universal priesthood. According to Claude Longeon, the main axis of the farce is its attitude to reason and rationality: Mercury, after all, is the symbol of cunning and craftiness. ${ }^{80}$ The farce against theologasters expresses a humanistic hope for reconciling reason and faith in the spirit of genuine piety.

\footnotetext{
76 La farce, 109.

77 Joachim Knape, 1521. Martin Luthers rhetorischer Moment oder die Einführung des Protests (Berlin: De Gruyter, 2017) 166-207, spec. 200.

78 See Johannes Schilling, Passio Doctoris Martini Lutheri: Bibliographie, Texte und Untersuchungen (Gütersloh: Mohn, 1989).

79 See M. Bakhtin, Rabelais, 312.

80 C. Longeon, "Introduction" in La farce, 22-34.
} 


\section{Poland without a Belly}

Given the considerable popularity of the word "theologasters" in France and the German Empire, a similarly warm reception could be expected in Poland, where attacks against the exceedingly lay lifestyle of the clergy were commonplace in the late medieval and early modern period. ${ }^{81}$ There were at least two arguments in favor of employing the already established Erasmian term: a strong connection between the political and intellectual elites and Erasmus as well as anticlericalism, which likely played a decisive role in the mass fascination with Reformation ideas. ${ }^{82}$ However, references to the "realm of the belly" never caught on in Poland, perhaps owing to a certain widely held structure of argumentation. According to Janusz Tazbir, whose analysis encompassed the entirety of Old Polish culture: "The most important charges formulated by Polish nobility against the clergy concerned material issues, the ignorance of certain priests, their excessively sumptuous lifestyle or charging inordinate fees for religious services. Contrary to print activity taking place in Western Europe (particularly Germany), sex-related matters came further down the list." 83

However, at the outset of the Reformation, there were no original publications in Poland that would attack Catholic clergy from a Protestant standpoint. Numerous texts from the German Empire were imported to Poland, most likely to satisfy the needs of a narrow circle of educated recipients. On the other hand, the catalogue of anti-Reformation works, mostly printed in Kraków during the reign of King Sigismund I (1506-1548), was rather extensive, as it encompassed almost thirty titles. ${ }^{84}$ It is precisely on the pages of one such literary disputation that one may find a unique example of the use of theologastri as an insult. This took place during the dispute between the canon of Poznań, Grzegorz (Snopek) of Szamotuły (Szamotulski), and the vice-chancellor

81 U. Augustyniak, "Wstęp" in Państwo świeckie czy księże? Spór o rolę duchowieństwa katolickiego w Rzeczypospolitej w czasach Zygmunta III Wazy. Wybór tekstów, ed. eadem (Warszawa: Semper, 2013) 7-128. See also Maciej Ptaszyński, Reformacja w Polsce a dziedzictwo Erazma z Rotterdamu (Warszawa:Wydawnictwa Uniwersytetu Warszawskiego, 2018) 295-316.

82 About Polish Erasmianism see Ch. Galle, "Bischöfe, Humanisten und einfache Lutherfeinde. Die Kontakte des Erasmus nach Polen im Spiegel seines Briefwechsels," Odrodzenie i reformacja w Polsce 116 (2017) 61-101; H. Louthan, "A Model for Christendom? Erasmus, Poland and the Reformation," Church History 83 (2014) 18-37; P.G. Bietenholz, "Concordia christiana. Erasmus' Thought and the Polish Reality," E RSY 21 (2011) 44-70; J. Glomski, "Erasmus and Cracow (1510-1530)," ERSY 17 (1997) 1-18.

83 J. Tazbir, "Staropolski antyklerykalizm," Kwartalnik Historyczny 109 (2002) 13-22 (16).

84 An overview in M. Ptaszyński, "Wie politisch war die Reformation in Polen?," Archiv für Reformationsgeschichte 112 (2021) [in press]. 
of the Lubrański Academy, Christopher Hegendorfer. ${ }^{85}$ Although the controversy concerned Poznań, Grzegorz prepared his text in Kraków and dated the preface to 12 May 1535, Cracovie ex meo museolo. ${ }^{86}$ The dispute provoked the publication of Hegendorfer's reply in Wittenberg, ${ }^{87}$ to which, in turn, Grzegorz again responded. 88

Grzegorz (d. 1541) was a typical representative of the academy of the late Middle Ages. ${ }^{89}$ Having received a solid academic upbringing (bachelor's and master's degrees in Kraków and the title of doctor obtained a few years later from a different university), he worked as a lecturer and preacher. For some years, he was the vice-chancellor of the cathedral school in Gniezno (15071509) and Kraków (1511-1513), in 1525 he became the canon of Poznań, and in 1533 took on the post of archdeacon in the same city. He could easily be described as the embodiment of a medieval clergyman, who abused excommunication and ruthlessly enforced the rents he was due. In spite of these activities, he was continuously associated with the Kraków academy where he lectured. His body of work - of a secondary, compilatory nature-is most striking in its defense of indulgences and reluctance to indulge in humanistic novelties.

The polemics against the humanist Hegendorfer published in Poznan aptly convey the canon's intellectual profile. In comparison with other anti-Lutheran polemics that appeared in Poland, Grzegorz's writings Anacephaleosis flosculos monogrammos and Vincula Hiipocratis [!] have a highly intellectual character. ${ }^{90}$ In the first work, Grzegorz defines nine arguments where he cannot concur with Hegendorfer. ${ }^{91}$ The most important points of contention were the methods of academic reasoning and the relationship between philosophy and theology. Hegendorfer criticized the system of knowledge for its idolatrous attitude toward Aristotle and the resulting preference for philosophy at the expense

85 See Stanisław Kossowski, Krzysztof Hegendorfin w Akademii Lubrańskiego w Poznaniu w l. 1530-1535, Monografia z dziejów odrodzenia i reformacji w Polsce (Lwów: Altenberg, 1905); I. Zarębski, "Hegendorfer (Hegendorfinus, Hegendorf) Krzysztof" in Polski Stownik Biograficzny, ed. K. Lepszy, vol. 9 (Kraków: Ossolineum, 1960-1961) 337-339.

86 Grzegorz of Szamotuły, Anacephaleosis flosculos monogrammos ex progynnasmatis Christophori Endorfini selectos complectens (Cracoviae: Ungler, 1535) A1v.

87 Christopher Hegendorfer, Querela eloquentiae (Vittebergae: Ioseph Klug, 1536).

88 Grzegorz of Szamotuły, Vincvla Hiipocratis ad alligandum caput Cristophori Endorfini giirgatum spirantis, (Cracoviae: Ungler, 1536).

89 "Grzegorz z Szamotuł" in Polski Stownik Biograficzny, vol. 9, 9o-91.

9o See M. Nowicki, "Profil wychowawczy Akademii Lubrańskiego na tle sporu Krzysztofa Hegendorfera z Grzegorzem Szamotulczykiem” in Ku źródtom wartości, ed. P. Orlik (Poznań: Wydawnictwo Naukowe IF UAM, 2008) 327-334.

91 Grzegorz of Szamotuły, Anacephaleosis flosculos, A1v . 
of theology. According to Grzegorz, the criticism of Aristotelian metaphysics formulated by Hegendorfer was a humanist attack at the very foundations of scholasticism, which relied on Aristotle's writings in its arguments. Grzegorz believed that his reasoning could be informed by the writings of Aristotle and Plato, while Hegendorfer urged primary reliance on the Bible "augmented" by rational argument. Therefore, at first sight, the humanist was arguing against the antique tradition, while the schoolman defended its authority. Even if it was obvious that not Aristotle, but the Bible and Church tradition, was the bone of contention, literally both adversaries expressed anti-Lutheran sentiment. They both defended the freedom of human will but differed in their line of argumentation. ${ }^{92}$

Aside from methodological concerns, the debate focused on ecclesiology. Wanting to prove that Hegendorfer was in fact a crypto-Lutheran, Grzegorz criticized the notion of a universal priesthood promoted by the humanist, treating it as a return to the tradition of sycophants preaching against compensation, and as paving the way for children and women to access both the pulpit and the power of the keys (potestas clavium).${ }^{93} \mathrm{He}$ pointed out that the vice-chancellor had in fact reiterated the Lutheran definition of the Church as a congregation of saints headed by Christ himself. ${ }^{94}$ To Grzegorz, this ignored the visible manifestation of the Church, which was of utmost important to him. ${ }^{95}$ The Church was a body (corpus) made up of various members (membra), or-in other wordsa hierarchic institution. ${ }^{96}$ Ordained Church hierarchy had the power of the keys, which included both preaching the word of God in churches (templa) as well as giving the Eucharist and hearing oral confessions. ${ }^{97}$

\footnotetext{
92 Ibidem, $\mathrm{A}_{3}{ }^{\mathrm{r}}-\mathrm{Cr}^{\mathrm{r}}$.

93 Ibidem, $\mathrm{C}_{2}$ : "Verum hunc Sicophantam facile constat. Lutheranismo subscribere, dum omne hominum genus predicare Evangelii virtutes temere impudens afferat missum. Si quidem perfidus Lutherus, omnes Christiano exequo affirmat esse sacerdotes, proinde non solum Evangelium predicare, verum absoluere iuxta pueros ac mulieres putat atque papam, et reliquos, quicunque censentur Christiano vocabulo."

94 Ibidem, D1r: "Credo sanctam Ecclesiam catholicam sanctorum communionem quod aliud est nihil quam certussimum esse cetum quendam hominum Christianorum qui sanctorum communio vel sodalitas appellatur, qui cetus [!] hominum sanctus est que spiritu sancto regitur, impellitur gubernatur per spiritum sanctum, unam fidem unum baptisma profiteatur."

95 Ibidem, D1v: "Sunt quippe heretici et Schismatici qui Ecclesiam in solo spiritu consistere putant, neque visibiliter cognosci eam, sed latentem et ocultam volunt, quibus id imposuit, que omnia externa opera damnant, nullisque vel ceremoniis vel operibus declarare volunt se se ad idem corpus Ecclesie pertinere."

96 Ibidem, $\mathrm{Fr}^{\mathrm{r}-\mathrm{v}}$.

97 Ibidem, $\mathrm{E}^{\mathrm{r}-\mathrm{v}}$.
} 
One of the more interesting elements of Grzegorz's reasoning was the open and very tolerant character of this ecclesiology. The visible form of the Church was a mixed one, as evil people also belonged to it. ${ }^{98}$ Tares and wheat would grow together until the harvest, and wise maids would coexist with foolish ones. ${ }^{99}$ These formulations and rhetorical figures were common among antiLutheran polemicists who spoke out against the Reformation from the standpoint of tolerance. The aim of this argumentation was to show that the essence of Reformation consisted of relatively trivial abuses of office, which the Church could deal with using existing structures.

The most important theological controversy, justification by faith, was the last point Grzegorz made. ${ }^{100}$ The canon accused Hegendorfer of relying on a simple syllogism to prove that humans can only be justified by their faith in Christ: either people are justified by Christ or else he died in vain, yet since we know that Christ did not die in vain, people are justified by faith. To Grzegorz, this line of reasoning resonated with the thoughts of Luther. However, the archdeacon believed that Luther's understanding of Saint Paul's idea that "the righteous will live by faith" (Rom. 1:17; Gal. 3:11) was mistaken and too narrow. According to Grzegorz, Paul's idea of faith also encompasses fasting and deeds. ${ }^{101}$ Thus, the conclusion of the dissertation was clear: Hegendorfer was a Lutheran.

Hegendorfer's response was a great praise of humanism dedicated to Andrzej Górka, at the time the castellan of Kalisz. Although eloquence was a relatively recent addition to Sarmatian Poland, the humanist argued, it had already borne tremendous fruit, cleansing schools from barbarism. It had also polished a number of diamonds Sarmatia was replete with, to mention but

98 Ibidem, $\mathrm{D}_{2}^{\mathrm{r}}$ : "nempe Ecclesiae dones occurramus omnes in unitate fidei et que omnia membra declarant visibilem Ecclesiam non solum ex cetu sanctorum, sed et malorm permixtam."

99 Ibidem, $\mathrm{D}_{2}^{\mathrm{v}}$ : "Simile est regnum coelorum homini qui seminavit bonum semen in agro suo, inimicus tamen superseminavit Zizania in medio tritici, que paterfamilias permisit crescere usque ad messem [...] Ex quibus omnibus claret. Ecclesiam non solum esse cetum sanctorum, sed etiam esse collectam ex bonis et malis ex vuis et balruscis." About the parable of the tares and the wheat (Mt 13, 30) see Arnold Angenendt, 'Lasst beides wachsen bis zur Ernte': Toleranz in der Geschichte des Christentums (Münster: Aschendorff, 2018).

100 About the role of justification by faith see I. Dingel, "Wie lutherisch war die Wittenberger Reformation. Von konfessioneller Vielfalt zu theologischer Profilierung” in Initia Reformationis. Wittenberg und die frühe Reformation, hrsg. von I. Dingel et al. (Leipzig: Evangelische Verlagsanstalt, 2017) 409-428 (426); A. Beutel, “'Wir Lutherischen': zur Ausbildung eines konfessionellen Identitätsbewusstseins bei Martin Luther," Zeitschrift für Theologie und Kirche 110 (2013) 164-170.

101 Grzegorz of Szamotuły, Anacephaleosis flosculos, G2v. 
Andrzej Krzycki, Jan Dantyszek, Bartłomiej Stawiski, Józef Struś, or Stanisław Hozjusz. ${ }^{102}$ The reform of schools in Kraków and Poznań had yielded amazing results, but the remaining Sarmatian centers were still imprisoned in fetters of "Scythian tyranny" that continued to employ the works of Alexander Gallus and Petrus Hispanus. The products of such education were philobarbari, who ought to be countered with the instructive and useful writings of Cicero. ${ }^{103}$

Refuting these charges, the clearly irritated Grzegorz called Hegendorfer a "quarreler and theologaster."104 Somewhat paradoxically, the insult employed by German and French humanists and Protestants against scholasticism ruling academia was used here by a defender of traditional academic culture and the Roman Church against a humanist and Protestant.

However, at the outset of original Protestant print activity in Poland, at the turn of the 1550s, no one employed the Erasmian insult. The term was only reused by Andrzej Wolan (Andreas Volanus) (1530-1610), who-given his contribution to the development of Protestantism in the Grand Duchy of Lithuania - was dubbed the pope of Lithuanian Calvinists by historiographers. ${ }^{105}$ Having arrived in the Grand Duchy, this nobleman from Greater Poland, who owed his career to Mikołaj "the Red" Radziwiłł in the Grand Duchy of Lithuania, became closely associated with the Reformed Church of Vilnius. Among his many activities, he was an indefatigable writer, entering into disputations with both Catholics and Antitrinitarians.

In his polemics with the Antitrinitarians Szymon Budny and Fausto Sozzini (Faustus Socinus), Andrzej Wolan spoke out several times representing the camp of erudites and scholars. ${ }^{106}$ In a complete reversal of the original Protestant argumentation, known from the confrontation between Melanchthon and

\footnotetext{
102 Christopher Hegendorfer, Querela eloquentiae, $\mathrm{A}_{2}{ }^{\mathrm{r}}-\mathrm{A} 3^{\mathrm{r}}$.

103 Ibidem, $\mathrm{A}_{4}^{\mathrm{r}}$.

104 Grzegorz of Szamotuły, Vincvla Hiipocratis ad alligandum caput Cristophori Endorfini, D8 ${ }^{\text {r- }}$ v: "Audique quid egregius iste Iurgista et Theologaster tandem aggreditur per haec verba."

105 See Kęstutis Daugirdas, Andreas Volanus und die Reformation im Grossfürstentum Litauen (Mainz: Vandenhoeck \& Ruprecht, 2008) 19-182.

106 Andreas Volanus, Paraenesis Andreae Volani Ad omnes in Regno Poloniae, Magnoque Ducatu Lituaniae Samosatenianae vel Ebioniticae doctrinae professores: Eiusdemque ad nova Ebionitarum contra Paraenesin obiecta, Responsio (Spirae: Albin, 1583) 37. About his opponents see Kęstutis Daugirdas, Die Anfänge des Sozinianismus: Genese und Eindringen des historisch-ethischen Religionsmodells in den universitären Diskurs der Evangelischen in Europa (Göttingen: Vandenhoeck \& Ruprecht, 2016) 53-164; Stefan Fleischmann, Szymon Budny: ein theologisches Portrait des polnisch-weißrussischen Humanisten und Unitariers (ca. 1530-1593) (Köln: Böhlau, 2006) 69-122.
} 
the Sorbonne, Wolan argued that only prolonged contact with theological writings entitled one to preach, ${ }^{107}$ and he refused to acknowledge laypersons' right to interpret the Bible or have their say in matters concerning theology. ${ }^{108} \mathrm{New}$ writers (scriptores Neoterici) neither knew the Scripture nor Greek or Hebrew, and they made mistakes in Latin. ${ }^{109}$ These theologasters did not in fact practice theology, but a poor version of philosophy—or, as he goes on to add — not even philosophy, but mere grammar. ${ }^{110}$ Therefore, Wolan's advice was to bring these supposed masters down to earth."11

Consequently, the term coined by Erasmus, when employed by this fine Calvinist polemicist - as in the case of Grzegorz of Szamotuly - was meant to stigmatize unorthodox science. Contrary to Erasmus, Luther, Melanchthon, Calvin, or Beza, Polish polemicists used the insult not to expose the incompetence of people holding academic titles and representing powerful institutions. This term did not serve to undermine the authority emanating from representatives of established paradigms. Like Eck, Grzegorz and Wolan spoke from entirely different positions: as defenders of hierarchy and order against careerists and heretics. Therefore, in their eyes, the term "theologaster" maintained its etymological meaning - they were criticizing the pseudo-theologians who lacked the required qualifications and therefore were not entitled to enter into deliberations concerning God. On the other hand, the other meaning, based on false etymology and denoting the "sphere of the belly" - with its connotations of sin, carnality, and eroticism—disappeared.

\section{Paths of Transfer}

Last but not least, the forms of communication through which the term theologastri reached its recipients deserve some consideration. Having left behind

107 Andreas Volanus, Paraenesis, 25: "Imo quis unquam extitit, aut etiamnum existere potest, qui cum aliquo fructu, \& admiratione hominum sive viva voce, sive scriptis in Ecclesia populum Dei docere possit, nisi diu multumque in libris divinorum istorum scriptorum versatus?"

108 Ibidem, 37-38: "Idiotae autem vel scioli, qui leviter prima artium fundamenta degustarunt, nec quanta etiam sit exquisitae doctrinae amplitudo, degustare poterunt, hanc enim de se in animis opinionem concipiunt, quod in arcem universae doctrinae conscenderint, \& ultimam illam omnis scientiae metam attigerint. Hoc vero si quando perspici potuit, hac potissimum aetatae nostra animadvertere facile quisque potest."

109 Ibidem, 55-57.

110 Ibidem, 131-132, 139-140: "En quae monstra nobis novi isti Theologastri parturiunt."

111 Ibidem, 40. 
the circle of handwritten correspondence and polemic rough-and-tumbles that - until 1518-were also limited to manuscripts, pseudo-theologians found their place in ephemeral printed works (Flugschrift and Flugblatt) published in the German Empire in vast quantities with large circulations. According to estimates, around 200,000 titles were published in the German Empire in the sixteenth century; at least 10,000 appeared during the most intense clashes between Lutherans and Catholics (1520-1530).112 The circulation of some printed works is estimated at a thousand copies, and the most widely read works - such as the translation of the Bible or Luther's Small Catechism - were printed in more than 100,000 copies. ${ }^{13}$

While ephemeral printed productions were the mass medium of Reformation in the German Empire, elsewhere, their impact was much lower. ${ }^{114}$ Contrary to Luther and his followers or polemicists from the German-speaking realm, the author of La Farce des Théologastres did not publish his apology as an ephemeral printed work but prepared a theater play instead. Consequently, the example of France may prove that other forms of communication maintained their position even after the popularization of print, and, what is more, that they also played an important role in disseminating Reformation ideas. ${ }^{115}$ The mass media in the form of sermons, songs, and the theater are much more difficult for historians to capture than the relatively well-preserved printed material, but their scope must have been incomparably greater. ${ }^{116}$ The number of short plays (morality plays, farces, monologues) written in France in the fifteenth and sixteenth centuries is estimated at $c .250$, out of whichaccording to André Tissiera—around 200 works have the word "farce" in the

112 A. Pettegree, "Die Reformation als Medienereignis" in Aufbruch in eine neue Welt, hrsg. von H. Meller et al. (Dresden: Sandstein Verlag, 2016) 115-121; Nina-Maria Klug, Das konfessionelle Flugblatt 1563-1580: eine Studie zur historischen Semiotikund Textanalyse (Berlin: De Gruyter, 2012) 28-6o; and Mark U. Edwards, Printing, Propaganda, and Martin Luther (Berkeley: University of California Press, 1994).

113 See a useful summary in M. Nieden, "The Wittenberg Reformation as a Media Event" in European History Online (EGO), ed. Leibniz Institute of European History (IEG), Mainz 2012-O7-27. URL: http://www.ieg-ego.eu/niedenm-2012-en URN: urn:nbn:de:0159-2012O72 708 [access 18 January 2021].

114 J.-F. Gilmont, "Pour une typologie du 'Flugschrift' des débuts de la Réforme," Revue d'Histoire Ecclésiastique 78 (1983) 788-8o9. For Polish bibliography see Konrad Zawadzki, Gazety ulotne polskie i Polski dotyczace XVI-XVIII w., 3 vols. (Wrocław: Ossolineum, 19771990).

115 Adam Fox, Oral and Literate Culture in England 1500-1700 (Oxford: Clarendon Press, 2000) $5^{-36 .}$

116 J. Beck, Théâtre, 17-43. 
title. ${ }^{117}$ In France, the means used to carry Reformation ideas were still largely the manuscript and the spoken word, thus constructing a slightly different public sphere than in the area of influence of German printing presses.

The question of the structure of the public sphere of Reformation in Poland is even more difficult. In the times of Sigismund the Old, Protestant works were almost solely imported (also from neighboring Königsberg) and very rarely reprinted. The dimensions of the import of books "brought in by the barrelful"-as numerous bishops used to complain - will have to remain unknown. Information about Lutheran plays or carnival performances is similarly scarce. ${ }^{118}$ On the other hand, the sphere of print, delineated by officially published and sold works, had an anti-Reformation character, something that only changed in the mid-sixteenth century, alongside the founding of Protestant church organizations with their own printing presses that could operate thanks to the support of powerful patrons. ${ }^{119}$ Yet the mechanism of their establishment and their way of functioning resulted in an entirely different character than the public sphere of Reformation that had formed in the German Empire in the first half of the century thanks to the eruption of ephemeral printed matter. This difference was also reflected in the use of the term theologaster.

\section{Outlook and Summary}

The aforementioned cases constitute a collection of the most significant examples of the insult theologasters in the sixteenth century. Of course, the term was also known in the seventeenth and eighteenth centuries, and it even made it to ephemeral print material published during the Thirty Years' War. ${ }^{120}$ It appeared on the pages written by erudites, such as Melchior Adam, author of the list of

117 A. Tissier, "Introduction" in Recueil de Farces (1450-1550), ed. A. Tissier, vol. 1 (Genève: Droz, 1986) 15; J. Beck, Théâtre, 29.

118 See Monika Kuleczka, Między sztuka a religia: dramat i teatr protestancki w Prusach Królewskich (Gdańsk, Toruń, Elblag, 1550-1650) na tle mieszczańskiej kultury materialnej $i$ duchowej (Kraków: Collegium Columbinum, 2011).

119 This aspect was omitted in the monograph by Natalia Nowakowska, King Sigismund of Poland and Martin Luther. The Reformation before Confessionalization (Oxford: OUP 2018).

120 Bedencken eines Theologastri, Gestellt Wider die Erinnerung Der redlichen Teutschen Landsknechts. Sampt Des Landsknechts Antwort auff das Bedencken mit angehengten Thesibus, so der Landsknecht dem Bedencker zu examiniren fürstellet: Und einer kurtzen Vorrede an den gönstigen Leser (s. l., 1630). 
famous theologians and lawyers, ${ }^{121}$ Erasmus Finx (Erasmus Francisci), a polyhistor who praised the victorious battle of Vienna (1683), ${ }^{122}$ and Baruch Spinoza (as well as his critics). ${ }^{123}$ Robert Burton also used it in his famous Anatomy of Melancholy, as a result of which the term found a permanent place in English dictionaries. ${ }^{124}$ In the eighteenth century, the insult could be found not just in the writings of the investigators of Spinoza's philosophy (like Hermann Samuel Reimarus or Gotthold Ephraim Lessing ${ }^{125}$ ), but also in polemics published by Pietists (Johann Melchior Stenger ${ }^{126}$ ) and orthodox Lutherans (Abraham Calov). ${ }^{127}$ However, by that time, the term was already past its heyday, and was

121 Melchior Adam, Vitae Germanorum iureconsultorum et politicorum: qui superiori seculo, et quod excurrit, floruerunt (Heidelbergae: heredum Ionae Rosae, 1620) 145.

122 Erasmus Francisci, Schau- und Ehren-Platz Christlicher Tapfferkeit (Nürnberg: Endter, 1684) 30 on Thomas Ebendofer: "der verkehrte und nicht sonders gelehrte grobe Theologaster."

123 Baruch Spinoza, Tractatus Theologico-Politicus, hrsg. von G. Gawlick, F. Niewöhner (Darmstadt: Wiss. Buchges., 1979) Cap. XVII "Nam non dubium est, quin inter tot millia multi importuni Theologastri reperti fuerint"; Christian Kortholt, De tribus Impostoribus magnis liber (Kilonii: Reumann, 1680) 178: "Quibus cum ceteras omnes impietates suas superstruat profanus Theologaster, nihil tamen minus agit verbosis suis disputationibus, quam ut ulla idonea probationea ea fulciat, sed ubique, vult certissima axiomata."

124 Robert Burton, Anatomy of Melancholy, ed. Th.C. Faulkner, vol. 1 (Oxford: Clarendon Press, 1989) 325: "Theologastri (solvant modo) satis superque docti, per omnes honorum gradus evehuntur \& ascendunt"; see ibidem, vol. 4: Commentary, ed. J.B. Bamborough, M. Dodsworth (Oxford: Clarendon Press, 1998) 347-350.

125 [Hermann Samuel Reimarus], "Fragmente eines Ungenannten" in Gotthold Ephraim Lessing's sämmtliche Schriften, vol. 10, hrsg. von K. Lachmann (Leipzig: Göschen, 1856) 18: "Wie leicht waren jene Theologaster zu widerlegen, die außer einigen mißverstandenen Schriftstellen nichts ans ihrer Seite hatten, und durch Verdammung der Vernunft die beleidigte Vernunft im Harnisch erhielten! Sie brachten alles gegen sich auf, was Vernunft haben wollte, und hatte." Comp. also: https://www.hs-augsburg.de/ harsch/germanica/ Chronologie/18Jh/Reimarus/rei_froo.html (access: 17 January 2021). See K.H. Rengstorf, "Lessings Ansatz in seiner theologischen Arbeit" in Religionskritik und Religiosität in der deutschen Aufklärung, hrsg. von K. Gründer, K.H. Rengtorf (Berlin: De Gruyter, 1989) 101113 (102); Dietrich Klein, Hermann Samuel Reimarus: (1694-1768) (Tübingen: Mohr Siebeck, 2009) 169-181.

126 Johann Melchior Stenger, Secta cervicodurorum 4. Reg. 17, 14 seu concupiscentiariorum 2, Tim. 3, 6, 7, 8 historiae ecclesiasticae ... de hartnaccismo (s.l. 1681) G33: "Ast Calovio dicuntur hi duo 'Stümpeleri', id est 'semidocti Theologastri'” Most probably, Stenger refers here to Censura Stengeriana (Erfurt: Hertz, 1671) 208: "diese Hümpeler in rebus Theologicis und praxi vielleicht wenig versiret" so the expression "semidocti Theologastri" is not a quotation, but a paraphrase of Calov's expression. About this controversy see U. Sträter, "Philipp Jakob Spener und der 'Stengersche Streit', Pietismus und Neuzeit 18 (1998) 4079 .

127 Abraham Calov, Historia Syncretistica, Das ist: Christliches wolgegründetes Bedencken über den Lieben Kirchen-Frieden und Christliche Einigkeit In der heilsamen Lehre der Himmlis- 
used not so much as an argument or an insult, but rather as a relic of scholarly character, an Erasmian symbol.

To sum up, it is worth taking another look at the history of this bizarre insult. In the early writings of Erasmus, the term "theologaster" meant, above all, an aversion to institutionalized science and the form it took on in the times of scholasticism. His complaints resonate with the overtones of an underrated expert excluded from the academic world, where his competence was neither valued nor necessary. The meaning of this term, like the general attitude evinced by Erasmus, was marked by an ambivalent mix of rejection and aspirations. Presuming this image of the unappreciated scholar, complaining against the academy, was at least partially true, the self-perception of Erasmus must have changed over the years as the humanist joined the academic world, teaching in Cambridge, helping in establishing the university in Louvain and holding the position in Basel. This might explain why the Latin neologism did not become a permanent feature in his writings, even when he accused schoolmen of demonstrating an excessively irreverent approach to classical tradition. Nevertheless, the insult became generally known with the publication of the eminent humanist's correspondence.

On the eve of the Reformation, the term was mostly appreciated by Catholic polemicists. It was used to emphasize the incompetence of representatives of fledgling confessions, who did not have the required tools to interpret the Bible and, thus, no right to become involved with it. Behind this criticism was the fundamental dispute about the significance and importance of the Church for religion. In a number of disputations all over Europe, Catholic polemicists tried to argue that the Bible was a difficult text, whose interpretation was rooted in tradition and belonged to an institutionalized Church. Lay know-it-alls had no legitimacy to take on said task.

On the other hand, in the language of Protestant theologians of all confessions, the term was used to criticize Catholic polemicists, most often scholastics

chen Wahrheit: in Dreyen Büchern verfasset (s.l. 1685) 873: "a quibus seducti sunt Novatores nostri, exposita à lumine et columine Juliano Calixto, quem ita aestimat Theologaster ille Medicus"; Abraham Calovii D. Biblia Testam. Veteris Et Novi Illustrata, In Quibus Simul Annotata Hugonis Grotii Exhibentur (Dresdae; Lipsiae: Zimmermannus; Rudolstadii: Urban; [Hildburghausen]: Pensold, 1719) 1241: "Equidem non existimo vulgatum interpretem, quod ita hunc locum verti, 'nescit homo amorene an odio dignus sit, ita intelexisse', ut voluerit Saomon, quod Theologastri credunt, dubitandum esse de Dei amore in nos"-Calov quotes here a Bible commentary by the French humanist Jean Mercier: Ioannis Merceri ... commentarii in Salomonis Proverbia, Ecclesiasten, et Canticum canticorum: Adiecimus ad calcem horum Commentariorum Harmoniam sive Tabulas utilißimas in Proverbia et Ecclesiasten (Genevae: Vignon, 1573) 128v . 
from the Sorbonne. Gradually, as churches became more and more institutionalized, it was also used as an argument against various radical Reformation movements, as demonstrated by Wolan's disputation with the Antitrinitarians. The Confrontation between Lutheran Orthodoxy and Pietism could serve as another example of the implantation of the humanist slur. While criticizing the dilettantism or radical rationalism of their opponents, they simultaneously praised institutional knowledge. Perhaps without being fully aware of that, Protestant polemicists were reiterating the gesture of their Catholic adversaries.

The above deliberations do not claim to reconstruct the vocabulary used by cultures of conflict in the modern era. Their aim was to demonstrate by way of a meaningful and unique example the role of humanist culture in the development and shape of the Reformation movement. Bernd Moeller formulated a radical version of this thesis with his provocative statement that "without humanism there would be no Reformation." ${ }^{28}$ Even though the proposal was largely accepted (especially among researchers of humanism), in certain studies - often very one-sided - the relationship between humanism and Reformation comes down to a shared interest in ancient languages and the Bible, to the conflict between Erasmus of Rotterdam and Martin Luther concerning free will, and the question of reforming the Academy as proposed by Melanchthon. The history of the term coined by Erasmus demonstrates therefore both the depth of the ties between both spheres and their complex nature.

\section{Acknowledgments}

This article was prepared as a part of the research project 2018/31/B/HS $/ \mathrm{oo}_{31}$ funded by the National Science Centre, Poland. For the translation, I am thankful to Aleksandra Szkudłapska; for the corrections and helpful commentsto Barry Kean, Anna Skolimowska, Kai-Ole Eberhardt, and the anonymous reviewers.

128 B. Moeller, "Die deutschen Humanisten und die Anfänge der Reformation," Zeitschrift für Kirchengeschichte 70 (1959) 46-61 (59). Moeller's thesis has been discussed by Cornelis Augustijn, Paul F. Grendler, Berndt Hamm, Thomas Kaufmann, Manfred Rudersdorf, Erica Rummel and Anton Schindling. 